\title{
Käringsjön. A Fertility Sacrificial Site from the Late Roman Iron Age in South-west Sweden
}

\author{
Anne Carlie
}

\begin{abstract}
In the beginning of the 1940s the sacrificial site at Käringsjön, in Halland, south-west Sweden, was investigated by Holger Arbman and Erik Floderus. Some years later the archaeological results were presented by Arbman in an exhaustive publication. Since then the site has been regarded as a typical example of the sacrificial sites used by the peaceful agrarian populations in the practice of the fertility cult. In this paper Käringsjön is brought up to renewed discussion. This is done i.a. by means of a structural analysis, in which is shown a very conscious use of the site. The sacrificial depositions are seen to closely correspond to the annual changes of the sun's movement in the sky when rising and setting on the horizon. It is here suggested that the sacrifices took place not only during different seasons but also at different times during the twenty-four hour day. Finally, the paper also deals with the questions of whether Käringsjön should be seen as a sacrificial site of local or of regional importance, and why the site was suddenly abandoned around 400 A.D.
\end{abstract}

Anne Carlie, Department of Archaeology, Stockholm University, SE-106 91, Stockholm, Sweden.

To me few archaeological sites have such a suggestive and imaginative atmosphere as Käringsjön, situated in the Nissa Valley near Halmstad in south-west Sweden. The former lake, used during the Late Roman Iron Age as a sacrificial site, has today a hidden location surrounded by a forest of firs and pines and lying far from the beaten track. The bog itself lies in a pronounced depression, surrounded by mighty hills on almost every side (fig. 1). Although most of the bog is now overgrown with small bushes and brushwood, there still remains a small area in the middle that is free from trees. More than 1600 years have passed since the small lake was abandoned as a sacrificial site, yet much of the mystery of the site remains. The special atmosphere is enhanced by the visual inaccessibility of the bog. With the surrounding dramatic topography, the site stands out as a small room or stage - perhaps deliberately chosen because of its hidden location in the landscape.

The ancient story of Käringsjön is long since finished and forgotten. From the archaeological investigation of the site in the 1940s, however, we can try to increase our understanding of the site and at the same time create new stories about the events and happenings that once took place.

\section{THE REDISCOVERING}

The modern-day story of Käringsjön begins about 80 years ago, in 1917, when prehistoric finds were made in connection with peat cutting in the bog. The finds included pottery as well as tree trunks that "had indisputable traces of being worked by man". The discoveries led in the same year to a minor excavation by Knut Kjellmark. In the investigation not only large amounts of pottery sherds were found but also 
a small piece of rope of lime-bast, different kinds of wooden artefacts, a cattle horn and charcoal. Furthermore there were found parts of a dense concentration of trunks and branches. In Kjellmark's opinion, the finds indicated that the bog had been used as a settlement some time during the Early Iron Age. This hypothesis was revised already the following year, however, when a complementary investigation was done by the archaeologist T.J. Arne and the geologist L. von Post.

Like Kjellmark before him, Arne had to restrict his investigations because of the high water-level in the bog. A small amount of trenches were opened along the north-western, southern and south-eastern edges of the bog. In these were found five clay vessels, a medieval iron axe with a broken handle, and parts of a wooden construction of worked or chopped trunks and branches. Arne himself felt dubious about the hypothesis of a settlement, and instead interpreted the bog as a sacrificial site from the Early Iron Age (Arbman 1954:10ff).

\section{THE INVESTIGATION OF 1941}

After the investigation of 1918 nothing much happened at the small bog. The archaeological finds were sent to the National Museum of History in Stockholm, and gradually the peat holes were overgrown. It would take another twenty years before the archaeologists again showed an interest in Käringsjön. Thus in the summer of 1941 new investigations of the bog were initiated by Holger Arbman and Erik Floderus. As before, the high water-level resulted in considerable practical problems. In order to carry out the excavations one had to dig a deep ditch towards the north, at which the level could be lowered by about one meter. Even after this lowering the bog was filled with a great deal of water and the excavations therefore, according to Arbman's records,

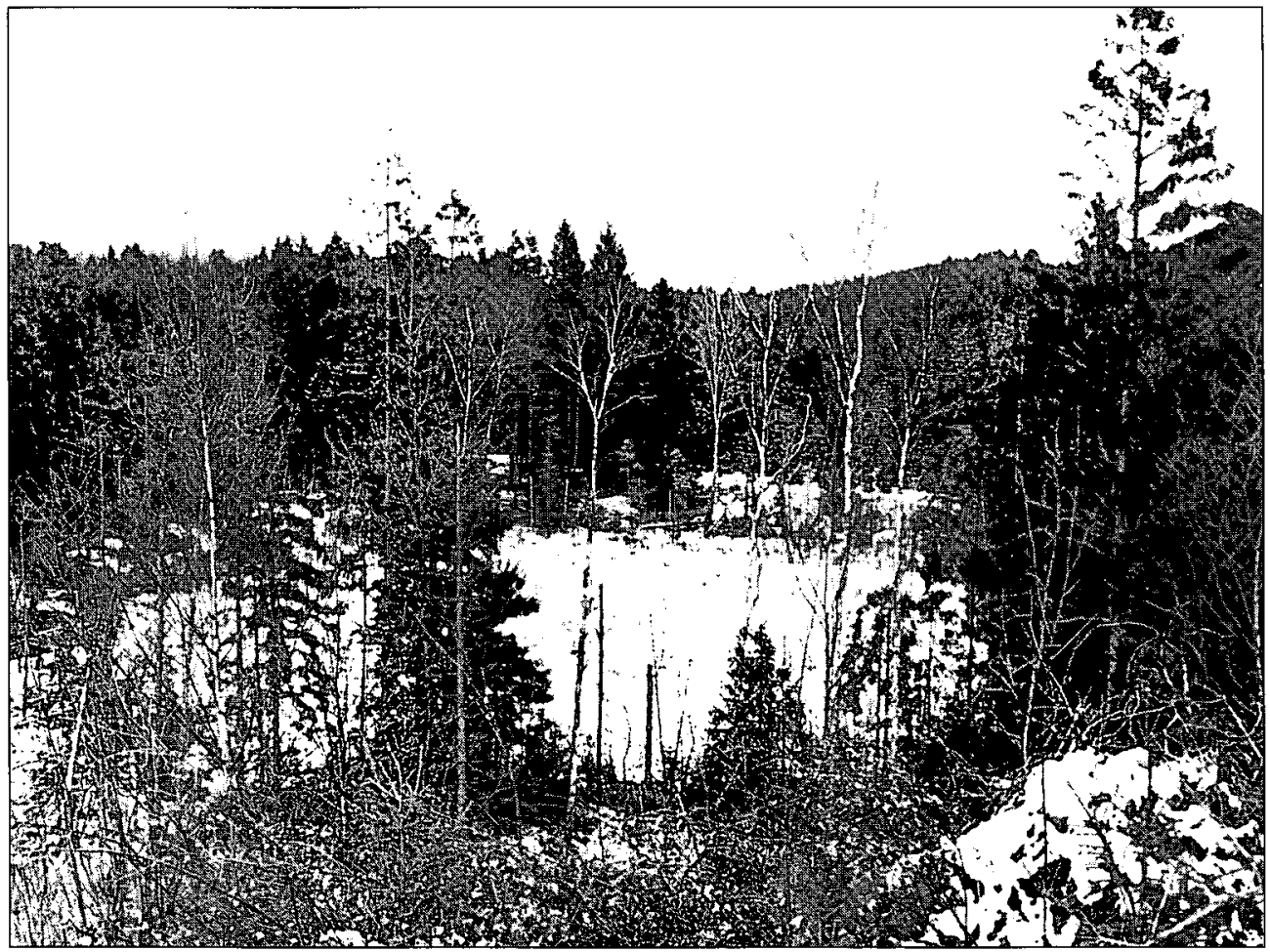

Fig. 1. The sacrificial site at Käringsjön is characterized by a conspicuous visual inaccessibility. Not until one approaches the site, does it open up as a stage in the landscape. Photo: Anne Carlie. 
were fraught with great practical difficulties (Arbman 1945:15f).

The scientific results of the investigation of 1941 were presented some years later by Holger Arbman in his book Käringsjön. Studier ihalländsk järnålder (1945). In the book there is given, even with today's standards, an unusually rich and extensive picture of Käringsjön from an archaeological, a geological and a cultural-historical point of view. A large amount of space is devoted to the description and interpretation of the finds and the constructions found in the different trenches. The ceramic material, consisting of almost 100 vessels, is the dominating find category from the bog. Through its rich and varying composition, the material offers good opportunities for interpretations of the shapes and functions of the vessels. The ceramics thus constitute an important basis for the chronological discussions concerning the sacrifices. Another find category that contributes to the scientific importance of the site is the unusually rich occurrence of wooden artefacts connected with an agrarian society. These implements give an interesting glimpse into the agriculture of that time - a picture that is usually missing on archaeological sites due to poor preservation conditions for organic materials.

The interpretation of Käringsjön, as a sacrificial site for fertility, is based on the character of the finds and on comparisons with similar finds from Denmark and southern Sweden. Here several different criteria are put forth in support of the sacrificial site theory, namely the occurrence of

- deliberately arranged wooden platforms

- deliberately deposited tools belonging to an agrarian population

- tools deliberately broken

- deliberately deposited clay vessels containing food offerings

- rich amounts of small white stones of quartz interpreted as votive throws

- charred branches and pieces of logs indicating that ceremonies can also have taken place during the night.
In his final interpretation of the site Arbman writes:

"From the character of the artefacts it is evident that it is the local farming population, that have deposited the votive offerings, and the reason for those sacrifices an agrarian population gives to higher powers can only be one, to persuade the deity of giving good crops and protecting the animals. We cannot in detail understand the world of meaning that is the basis for these sacrifices. For the farmers of that time they were not at all unimportant actions, they were just as necessary as sowing, harvest and the nurturing of cattle, they were a part of that times rational farming."

(Arbman 1945:110)

\section{AN ATTEMPT AT NEW INTERPRETIVE PERSPECTIVES}

Discussions concerning Käringsjön and what the site represents have been scarce in the archaeological literature since Holger Arbman's publication. On those occasions the sacrificial site attracted any attention, it has been presented either as a typical example of the collective fertility cult of the peaceful agrarian population, or as a comparative reference in the discussion on votive finds from the Iron Age (Stenberger 1979:425f; Arbman 1954:132f; Ström 1985:62; Becker 1970:160, 1971:46; Hagberg 1967:71 Bd II; Stjernquist 1973:32 and 46). Only in the last few years, in connection with an increasing interest among archaeologists for questions concerning ancient Nordic religion and cult, can one see a renewed interest in Käringsjön (cf. Artelius 1993; Lindberg 1994). No serious attempts to reinterpret the site have to my knowledge been presented. One might therefore ask whether Käringsjön as an archaeological site is "fully interpreted", or if it is possible, in spite of the thorough analysis by Arbman, to increase our understanding of the site and its meaning for the people of that time.

How one chooses to interpret an archaeological material depends on several different conditions. One important factor is the theoretical point of departure for the individual 
scholar. Is the aim of archaeology, by means of objective documentation and registration of finds and archaeological contexts, to reach the truth about man and society in prehistory? Or is the aim of the discipline instead, with the aid of a searching and interpretive attitude, to achieve a greater understanding of man in the past? In this searching process the individual plays an important and active role, using his/ her thoughts and experiences of today, as a tool to understand the past. Because I myself agree with the latter opinion, I think the time is ripe to bring up Käringsjön to renewed discussion.

With this searching process as a point of departure the aim of this paper is therefore to present a complementary story of Käringsjön. A story that will hopefully give a more vivid picture of the former cultic site and the votive offerings that once took place in and around the small lake. The archaeological finds from Käringsjön show that the sacrificial ceremonials were carried out during a period of almost 200 years, between 200 and 400 A.D. This range of time corresponds to no less than eight generations of 25 years each. A fundamental question in this connection is what kinds of sacrifices were made, and if these unambiguously support the hypothesis of a fertility cult. Where around the lake did the sacrificial ceremonials take place? How often did they occur-every year for almost two centuries, or in periods with several years in between? At what time of the year did the sacrifices take place?

Other questions for discussion include what importance the sacrificial site had for the nearby population of that time. Was the lake used as a collective site for a larger district, or are the votive deposits of Käringsjön instead the results of a local cult tradition? This last question is of great importance for the way in which we, from an antiquarian point of view, should consider Käringsjön. Should we see the sacrificial lake as a relatively unique phenomenon, or should we expect to find other similar sites in connection with every Iron Age settlement? Finally, I will also deal with the question of why the site was eventually abandoned.
In the analysis I will use both a traditional processual way of working, at the same time as I intend to apply a more humanistic way of thinking. In the latter case I will try to use a method of structuralism for the find material. The fundamental theory of meaning production in structuralism, initially developed within linguistics, is that the parts of a system receive their meaning through internal relations. Thus every word acquires its meaning by being set in relation to other words. Through the works of the French anthropologist Claude LeviStrauss, structuralism has also been applied to non-linguistic systems. In his studies within anthropology, Levi-Strauss sees man's way of classifying his surroundings - in opposites or binary oppositions - as a universal structure. The reason for this is that existence became structured and thereby possible to control intellectually. Thus the method of structuralism implies that it is possible, through the analysis of the relation between parts of a system, to deconstruct the underlying meaning, irrespective of whether the actors themselves are conscious of the matter or not (Levi-Strauss 1984; cf. Burström 1991:48f).

In my attempts to achieve a greater understanding of Käringsjön, I will also discuss sacrifices and fertility cult from a comparative religious-historical perspective. The historical documents concerning ancient religion in the Nordic region at the time Käringsjön was used, consist primarily of Tacitus' Germania from 98 A.D. Later descriptions of ancient Nordic religion derive from the time of the Scandinavian christian missions in the beginning of the 9th century and the closest following centuries. The next most important sources concerning pre-Christian cult are the Icelandic Edda poems and songs. These documents are, however, of a much later date (not written before the 13th century), and should therefore be used only with great caution as illustrations of how the cult may have been practised (for a closer presentation of the different sources see e.g. Turville-Petre 1964:1ff and Kaliff 1997:17ff). With regard to the source-critical aspects on using written sources of older times 
for interpretation of the ancient Nordic cult, these have recently been discussed by the religio-historian Anders Hultgård (Ibid 1996).

\section{ON IDENTIFYING RITUAL ACTIONS IN KÄRINGSJÖN}

It is of course not possible to identify and reconstruct in detail the ceremonies and sacrificial rituals that once took place in Käringsjön. In order to understand the meaning of the site the analysis will begin with a discussion of the different finds and constellations of finds that offer insight into the character of the cult. One method of identifying sacrificial actions on the site is to search for phenomena in the archaeological material that are unusual or, because of their recurrence, are possibly part of different rituals (Colpe 1970:34ff). Scholars of religious history see rituals as one of the basic constituents in connection with religious worship. The strength of the ritual lies in its repetitive character; the repeating of the ritual time after time has a transformative effect on the object or the context in which it is performed. By means of repetition the ritual is also protected against rapid change, at the same time as it has an important communicative function between the profane and the spiritual world (cf. Renck 1996:89ff; Bloch 1985). Another criterion of selection that will be used in the analysis is assumptions concerning the symbolic value of different find categories that have been put forth in the literature on the history of religion.

The following finds and find conditions will here be discussed more closely:

- the deposition of clays vessels containing offerings of food and drink

- the occurrence of deliberately destroyed clay vessels

- the deposition of different wooden tools connected with an agrarian society

- the deposition of bundles of flax and a flax holder

- the occurrence of numerous small white or light-coloured stones seen as votive offering throws
- the occurrence of permanent constructions for practising of the cult.

The deposition of vessels with food and drink offerings

The repeated depositions of clay vessels containing food and drink offerings are one of the most central characteristics of Iron Age fertility sacrifices (Becker 1970 and 1971). This is also the case in Käringsjön, where no less than approximately one hundred different vessels have been identified among the finds from the investigation of 1941. The ceramics are dominated by large situla- and barrel-shaped vessels, which before the sacrifice were presumably used partly for the storage of food and partly for cooking. Fine-ware pottery is also represented in the form of small bowls and elegant cups for drinking. Several vessels seem to have contained some sort of food offering at the time of deposition. Chemical analysis of burnt crusts from the vessels shows a composition of blood and malt or grain. Other vessels contained a gray-brown fatty substance which, in a more thorough chemical analysis contained, proved to have a high contents of animal fat. Due to the dispersive constituency of the fat particles, Arbman is of the opinion that it probably has nothing to do with substances of a smoothe and firm condition, such as butter or fat. Instead it seems more likely that it derives from intestines, in which concentrations of fat are more dispersed (Arbman 1945:107f).

\section{Ritual destruction of artefacts}

The sacred destruction of objects is a frequent phenomenon in Iron Age sacrificial finds. Probably the phenomenon is best known through the many bog finds consisting of booty sacrifices, for example the well-known sites of Nydam, Illerup Ådal and Ejsbøl mose in Denmark, and Skedemosse on Öland in southern Sweden. In connection with the sacrificial ceremonies, the confiscated weapons and other equipment of the enemy were carefully destroyed before being delivered to the gods. Swords and spearheads were bent and 
broken, clay vessels crusched, and horses were killed with spears and strokes that cracked their skulls. With ritual destruction the sacrificed object or animal was made unqualified for use in the profane world; sacrifice changed or transformed it into the property of the gods (Ström 1985:33f).

In Käringsjön the phenomenon of ritual destruction is much less dramatically manifested than in the sacrificial booty finds. Among the ceramics some ten vessels have been damaged in different ways. In five cases the neck of the vessels has deliberately been knocked off (D14, K10:2, L1, L2 and M1) (fig. 2). All vessels are of the beaker type with a biconical shape and high neck, and they probably had been used for some kind of drink offering. In another five cases larger vessels have also been deliberately destroyed. There are two vessels with barrel shape (C7 and G1) and three with situla shape (E2, G9 and L5),

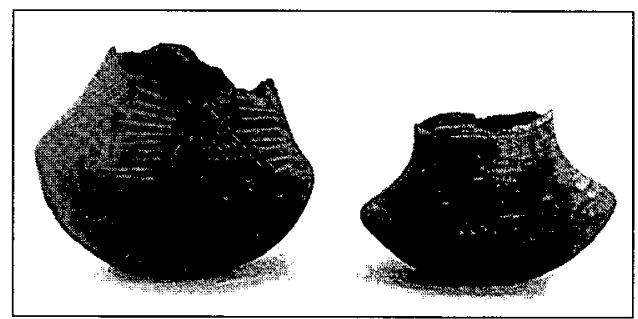

Fig. 2. Some of the clay vessels bear obvious traces of ritual destruction. The picture shows two examples, in which the neck of the vessel has been deliberately knocked off. Right: vessel L2; left: vessel M1. Photo: Anne Carlie.

in which small oval or rectangular holes had been deliberately knapped into the bottom of the vessels. In three cases a sherd from another vessel or a flat piece of granite had been placed over the hole. Arbman discussed the possibility of the holes having a magical purpose, but put this aside as the covering sherd or granite made possible a continous practical use of the vessels. He also refers to similar finds from the northern part of Jutland, where Gudmund Hatt has suggested that the vessels were used for cheese making. In this case, however, the holes must have been made before the pottery was burned (Hatt 1937:51). In my opinion, it is the recurrence of the holes that speaks in favour of these being made for a ritual purpose. One possible explanation why the vessels have been provided with "mended" holes could be the wish to create an illusion of the sacrificed liquid or drink gradually disappearing, in other words, as being consumed by the sacred powers of the lake. The phenomenon is also known from a sacrificial bog at Varbrogård, Bjergby parish, in the district of Hjørring in northern Jutland. In the 1940s a large amount of clay vessels (114, of which 85 were intact) was found in a small kettle bog with surrounding hills of a similar character as Käringsjön. When putting the vessels together it was noticed that several of them had knapped holes in the bottom. All vessels are of coarse ware and have been dated to the Early Roman period (Becker 1970:150f).

To what extent other vessels and objects have been ritually destroyed at Käringsjön is, however, difficult to conclude, since many of the damages registered in the find material could have arisen much later. Only in a few cases is it clear from Arbman's descriptions that we are dealing with damages made in older times. As an example one can mention C5-6 - a vessel of situla shape with a very narrow neck - that was found totally crushed in the trench. According to Arbman, the character of the fractures shows that this vessel had been crushed in ancient time. A further example is A6, a beaker with a band-shaped lug, which already at the time of deposition consisted of only one half of the vessel. Here Arbman makes a note that the half-vessel probably had been used for covering some kind of organic substance.

The occurrence of ritual destruction on a sacrificial site of peaceful character is interesting because it opens up for a broader perspective of the meaning of destruction. In societies practising a fertility cult the cultivation of land is often connected with different rituals. The destruction of votive offerings could be seen in this perspective as a symbolic 
"killing" of part of the year's harvest, which helps to set free the power needed for reconstructing the life of the earth and the power of growth in the following year. By means of ritual destruction one contributed to the rebirth of nature and crops and thereby secured a good regrowth and seasonal harvest (cf. Kaliff 1997:75f).

\section{The deposition of wooden artefacts, etc.}

As mentioned earlier, there were also found large amounts of wooden artefacts in the bog, which in different respects can be connected with the activities of an agrarian population. We are dealing with parts of rakes and different kinds of digging tools such as a mattock, a spade, and also a lekane and a tether pale. Among the finds were also a fine turned wooden box, a sliding cover decorated with a geometrical square pattern, a rectangular wooden trough and, finally, a wooden board probably used for cooking. Arbman for his part expresses some doubt about all the wooden items being votive offerings, as several objects were found in the peat without any closer connection to wooden constructions or other finds. On the other hand, he says, it cannot be denied that the tools actually have been sacrificed "in order to achieve a good seasonal harvest" (Ibid 1945:108). In my opinion it is primarily the recurrent deposition of tools connected with farming, that speaks in favour of them as being part of a ritual deposition. Also the artefacts have in several cases an obvious symbolic meaning: on the one hand they are closely linked to the earth-preparing activities and grazing of animals in the spring, and on the other hand to harvest and slaughter in the autumn. A deliberate deposition of wooden tools is also indicated by the fact that several objects have been broken in a manner similar to the clay vessels, before being deposited. This is the case for the two rakes as well as for the sliding cover with ornamentation.

\section{Deposition of bundles of flax}

Among the finds from Käringsjön there were also two bundles of flax and a flax holder of aspen wood. Historians of religion usually link the presence of flax to a special ritual and strengthening of meaning in the fertility sacrificial cult. This assumption is based on comparisons with the contents of Völsetaiten, the Flateyjarbok, written in the 15 th century, and the so-called find of Fløsand from Norway which consists of a bone knife with the runic inscription "linalaukaR", meaning flax and onion. In Völsetåten a story is told about a local fertility sacrificial cult in which, during the autumn slaughter, special attention was given to the phallos of the farm stallion - also called by the name of Völse. Later on it was the responsibility of the housewife to keep Völse together with strengthening herbs consisting of flax and onion, in order to make Völse grow in power so that "he might stand with the housewife if this is what she wants" (Steinsland \& Vogt 1981:93; Ström 1985:87f; cf. Hjørungdal 1991:103).

The finds of flax in Käringsjön thereby strengthen the view that the magical rituals performed on this cultic site were part of a fertility sacrificial cult.

\section{Votive offering throws}

A peculiar detail in the material from Käringsjön is the occurrence of numerous small stones of white or clear quartz and quartzite, found scattered in the bog. Since the stones were found both in connection with the pierlike wooden constructions and out in the bog itself, there is, according to Arbman, no doubt that they had been deliberately deposited. Arbman himself draw parallels with the tradition of votive offering throws, which are well documented in different parts of the world. He refers here to the ethnological literature (cf. Erixon 1917 and 1929), in which one usually distinguishes between votive throws of death and of fortune. The possibilities of further elucidating the meaning of the votive throws is, however, considered by Arbman to be limited (Arbman 1945:104ff).

Stones consisting of white quartz have in several cases been found in connection with different kind of burials. In the investigation 
of three Bronze Age mounds at Kårarp, some 3.5 kilometers south-west of Käringsjön, there were found in the central mound no less than 70 kilograms of white quartz and feldspar. This lithic debris, with pieces 2-20 centimeters large, was found in the upper layer of the mound within an area of $5 \times 5$ meters. In the stone-packing a secondary burial was found containing a band-shaped bronze fibula dating to the later part of the Early Roman period (Lundborg 1972:54ff).

Pieces of quartz have also been found at other sites in southern Halland, in connection with graves from the Early Iron Age. During the investigation of an Iron Age dolmen at Fröböke, Breared parish, no less than 130 pieces of white quartz were found (Arne 1919:130). (For further examples see Lundborg 1972:58f.) In my opinion, the fact that small white stones have been used in the burial customs of that time, speaks in favour of the hypothesis that also the stones found in Käringsjön have had a special religious or ideological meaning.

\section{Permanent constructions in the bog}

According to the geological investigations in Käringsjön, the site at the time of the sacrificial depositions consisted of a small lake with swampy shores. In order to strengthen the ground around the lake, simple platforms consisting of tree-trunks and branches were erected along the shores. The range of these wooden ramps or pier-like constructions, as Arbman also chooses to call them, varies between the different trenches. From his descriptions it can be concluded that wooden constructions of some sort probably existed along most of the shores, with an estimated largest width of about four to five meters. An element of uncertainty is that the structures in several places have been damaged in connection with peat digging in the beginning of the 20 th century. The platform structures vary considerably between the different trenches (cf. fig. 4). In several cases tree-trunks, chopped down into the lake, were registered together with fillings of small timber, branches and stones. Only in the eastern and southeastern sections of the bog was the timber structured in a more regular system, in that trunks of birch and oak had been placed parallel to the edge of the bog in six or seven different layers (Arbman 1945:18ff). Here it should be added that among the timber on the eastern side were found traces of charred branches and pieces of logs. Since traces of hearths and burned layers generally are lacking, Arbman suggests that the charred remains came from torches that were taken to or thrown out towards the lake (Ibid 1945:106).

The function of the platforms seems primarily to have been to make it easier to sacrifice in the lake, to give the vessels and other offerings to the powers of the lake. Thus it cannot be excluded that the platforms, as physical markers of the sacrificial site, also in time were ascribed some kind of symbolic meaning.

\section{The lack of bone and iron}

In one important respect the find material from Käringsjön differs from other known contemporaneous fertility sacrificial sites in wetland environments. Thus typical for many of these is the rich occurrence of animal bones, parts of human bones, and implements of iron. In Käringsjön these categories are almost totally lacking (cf. a cattle horn, a fragmentary jaw from an elk, and a birchwood handle belonging to an iron knife). Arbman himself does not discuss the question more thoroughly, that is, whether the lack of bone, horn and metal is real in the sense that these materials were not deposited on the site, or if the absence is secondary as a result of unfavourable conditions of preservation. If the acidity of the wetland is high (e.g. PH value 3-4) this will lead to the leaching of calcium and the disintegration of bone, at the same time as leather and skin are preserved. No analysis of the PH value has been made in Käringsjön. The fact that the knife blade was totally corroded speaks in favour of a high acidity (Arbman 1945:28). The find of a very well-preserved leather shoe from the Middle Ages also points 
in this direction. Thereby the lack of bone, horn and metal could be explained by the high acidity, resulting in the severe corrosion or destruction of these substances. However, the fact that isolated finds of bone and horn have been made in the bog speaks against such an assumption. If, for example, large amounts of bone had been deposited on the site, one presumably would have noticed the remains of these during the investigation in 1941, even if the bones were in a very bad condition. While no such information is reported, it seems more likely that the find material shows the real composition of the sacrificial depositions (after comments from Docent Ronnie Liljegren, Institution of Quaternary Geology, Lund).

\section{DATINGS}

Before continuing the analysis of Käringsjön, a brief account must be given of the chronology, with regard to the use of the sacrificial site. The dating of the cultic actions is primarily based on the ceramics from the bog. The main part of this material consists of coarse utility pottery, which because of its ordinary character gives little opportunity for closer chronological determination. As a basis for dating, Arbman instead uses the so-called "fine ware", characterised by distinct vessel shapes and in several cases also by ornamentation.

Among the finer ware Arbman distinguishes twelve vessels which, after comparison with grave finds from southern Sweden, Denmark and Norway, give a basis for the dating of the sacrificial site. The vessels dated consist of four beakers with a band-shaped lug, four beakers with a high neck and no lug, three bowls with a wide opening and, finally, a footvessel (Arbman 1945:42ff).

From the table in fig. 3 it can be concluded that three or four of the bowls, can be dated to the 3rd century A.D. The oldest dating is represented by a small vessel with a faceted foot, only twelve centimeters high. A comparison with finds from the Danish area shows that this type of vessel most likely have ceased to be manufactured before 200A.D. If we look at the other eight vessels, all are beakers of different types; five of them are dated generally to the 4th century, while three vessels have an ornamentation that places them in the latter part or end of the 4th century (Ibid 1945:42).

\begin{tabular}{|l|l|c|l|}
\hline Vessel & Type & 3rd century A.D. & 4th century A.D. \\
\hline A6 & Beaker with band-shaped lug & & $\mathrm{X}$ \\
\hline D14 & Beaker with high neck and no lug & & $\mathrm{X}$ (later part or end) \\
\hline D23 & Foot-vessei & $\mathrm{X}$ (early) & \\
\hline E3 & Bowl with wide opening and lug & $\mathrm{X}$ ? & \\
\hline G21 & Bowl with wide opening & $\mathrm{X}$ & \\
\hline H6 & Bowl with wide opening & $\mathrm{X}$ & \\
\hline K10:1 & Beaker with band-shaped lug & & $\mathrm{X}$ (later pari) \\
\hline K10:2 & Beaker with band-shaped lug & & $\mathrm{X}$ \\
\hline L1 & Beaker with high neck and no lug & & $\mathrm{X}$ (later part or end) \\
\hline L.2 & Beaker with high neck and no lug & & $\mathrm{X}$ \\
\hline M1 & Beaker with high reck and no lug & & $\mathrm{X}$ \\
\hline M2 & Beaker with band-shaped lug & & $\mathrm{X}$ \\
\hline
\end{tabular}

Fig. 3. Table showing those vessels that have been given a more precise dating within the Late Roman Iron Age. (After Arbman 1945).

Most of the vessels are considered to be of indigenous production. Only in two cases does Arbman suggest the possibility of imports. In one case it is a question of the previously mentioned foot-vessel, whose shape indicates a Roman provincial provenance. This type also occurs frequently in Jutland, however, so it is most likely an import from the Jutlandic district. The bowl H6 also shows great similarities with corresponding vessels on Zealand, and therefore this vessel is a probable import, according to Arbman.

The archaeological dating of Käringsjön is confirmed by the geological investigations in the bog (1918 and 1941). The investigations thus unambiguously show that the find-bearing layers belong to the time before 400 A.D., in other words the Late Roman period. Vegetation around the lake was at that time dominated by a birch forest, but also a mixed oak forest and alder and hazel occurred. Furthermore beech and hornbeam were beginning to appear in the area. Later on a deterioration of the climate, with more humid weather, resulted in an increase of the water-level of the lake (Arbman 1945: 116f; Sandegren 1945:157). 


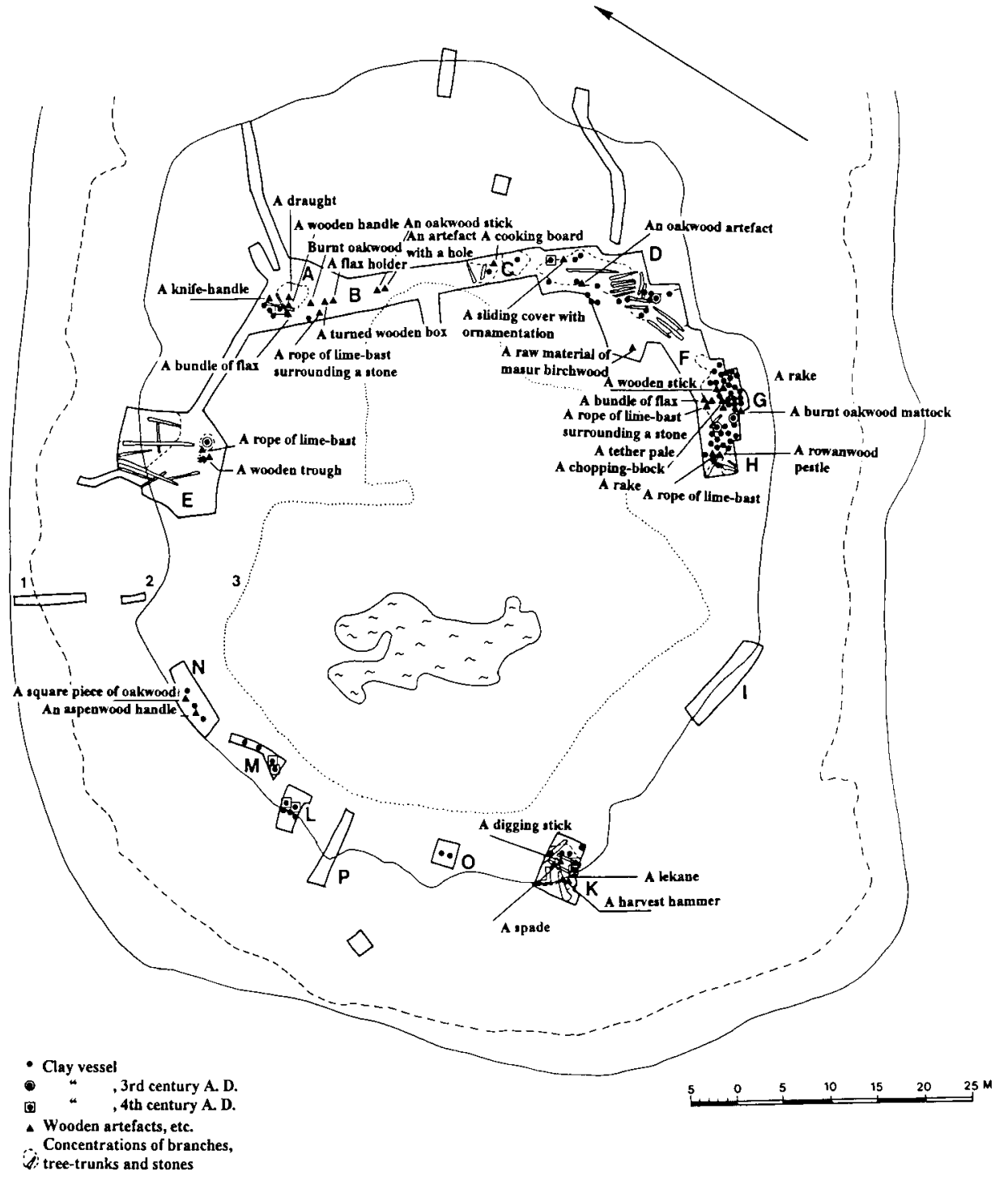

Fig. 4. A map showing the distribution of finds from the investigation of Käringsiön in 1941 (after Arbman's drawings, 1945).

$A-P$ mark the excavation trenches.

1 - Borderline for peat cutting in the beginning of the 20 th century.

2 - Borderline for large birch forest (1941).

3 - Borderline for permanent vegetation (1941).

Drawing: Anne Carlie. 
THE USAGE OF THE SACRIFICIAL SITE In order to study the changes in cultic activites over time, in the following pages I will make a comparative analysis of the spatial distribution of finds. In spite of the detailed presentation given by Arbman in his book, I miss an integrated plan of the spatial distribution of finds and structures. Therefore as a support for my own analysis, I have tried to reconstruct such a plan based on the drawings and find catalogues published in the book (fig. 4). A problem of source-critical concern is that the drawings for several of the minor trenches in the southern and western parts of the bog are missing in the book. Since the plans have not been rediscovered, the locations of the finds have a preliminary marking on the distribution plan. Another problem concerning the interpretation of the site, is that only the shores around the bog have been investigated and not the middle part. The results and conclusions presented in this paper may therefore be changed in the future through new and complementary investigations of the site.

When taking forth the plan in fig. $4 \mathrm{I}$ have chosen to include the following four parameters:

- all finds of clay vessels (dated vessels are marked)

- all finds of wooden artefacts, bundles of flax and rope of lime bast

- areas in which larger connected structures of wood and stone have been observed

- points of the compass and the annual movement of the sun in the sky.

From the distribution plan it is clear that the majority of vessels were found along the south-eastern and eastern edges of the bog. Although the trenches in the western part compose a much smaller area, they have also yielded a large number of finds. The amount of finds from the remaining areas is, however, low or non-existent. If one looks at the distribution of wooden artefacts and other finds of organic material, they show largely the same picture of distribution as the clay vessels, except for the western trenches in which the number of finds is considerably lower. It should also be mentioned that the same find categories are found in different locations along the edges of the bog. This is true both for the different types of digging and harvest tools found, as well as for those implements connected with cooking and the manufacture of flax.

Furthermore the distribution of finds corresponds to the more elaborate parts of the wooden construction found along the shores of the former lake. Arbman himself pays attention to this phenomenon and writes the following:

"Whether the offerings were placed in open water is not fully clarified. The clay vessels were generally placed on the timber, which apparently had been placed in order to get solid ground all the way out to the water. It is possible that the water-level gradually rose and the timber was lying under water at the time of the deposition of the vessels. However, some vessels have been placed without any connection to the timber and further out into the bog or lake." (Arbman 1945:106f).

Also marked on the distribution plan in fig. 4 are the find-spots of those twelve vessels which can be given a more exact dating within the Late Roman period (cf. fig. 3). As can be seen from the plan no less than three of the four vessels dated to the 3rd century A.D. were found along the south-eastern part of the bog, while the fourth vessel was found farther north. Of the eight vessels dated to the 4 th century, no less than six were found along the western part of the bog, whereas only two vessels were found along the eastern side.

According to the spatial distribution of the above dated vessels, the sacrifices were probably initiated in the beginning of the 3rd century A.D., and were at that time primarily located to the eastern and south-eastern shores and to some extent also to the northern shore. During the 4th century A.D. the sacrifices were carried out repeatedly along the western 
shores, at the same time as the ceremonies within the south-eastern area seem to be reduced for some reason. The lack of vessels from the time after the 4th century indicates that the lake was then abandoned as a sacrificial site. No evidence of a re-use of the site during the Late Iron Age can be traced in the find material. From the Middle Ages a leather shoe is preserved, which had probably been lost on the site.

There can be different explanations for the western shore also being used for cultic activities. One possible explanation is that the eastern shore gradually became more and more worn, and it was therefore decided to move some of the ceremonies to another and more intact part of the lake. This kind of rearrangement would, however, have involved a considerable amount of work, in view of the building of new wooden ramps or platforms. This would be a greater work endeavour than simply strengthening the already existing structures in the eastern part.

Another possible scenario could be that the lake was initially used as a sacrificial site for a single farm or village. The reason for sacrifices also being carried out on the western shore could then be that the site was used by yet another farm or village in the surrounding area. But this explanation does not seem particularly convincing, since it doesn't explain why the activities on the eastern shore declined. The question therefore is whether the sacrificial depositions instead should be discussed or understood from an ideological or religious frame of interpretation.

\section{ASPECTS ON THE CULTIC ACTIVITIES}

The exercising of the fertility sacrificial cult is a phenomenon which is generally closely connected with agrarian societies. A characteristic feature within the cult is the control of the sacred powers of vegetation and life. Different kinds of sacrifices and ritual actions are therefore needed in order to receive the blessing of the powers for next year's growth and crops. The only written source contemporaneous with Käringsjön that describes how the ancient cult tradition could have been exercised, is Tacitus' script Germania. In this he describes the so-called cult of Nerthus, of the Germanic tribe Ingvaones, which during the Roman Iron Age supposedly lived in southern Jutland and north-western Germany (corresponding to Schleswig-Holstein). Tacitus tells of seven different tribes, all worshipping the same goddess by the name of Nerthus. Of the goddess, Tacitus says that she, Mother Earth, intervenes in man's destiny and travels around among the people. Furthermore Tacitus describes a ceremonial feast in honour of the goddess, where she is accompanied by the priest in a carriage drawn by cows. On each site she visits there are feasts and days of joy. People do not go to war or carry any weapons, but think only of peace and tranquility. After the ride the carriage and clothing of the goddess are washed by thralls in an isolated lake, whereupon the thralls are swallowed by the lake (Tacitus 1976; cf. Holtsmark 1992:14; Ström 1985:40f).

Today no information is available concerning the division of the ancient year in the centuries just after the birth of Christ. Not until much later, during the Viking Age, do we have information that the year was divided into two halves - a summer and a winter season. The winter season started in the middle of October, while summer began in the middle of April (Ström 1985:91). According to Snorre, people had the custom of "greeting the winter" with a sacrifice in autumn and "greeting the summer" with a sacrifice in spring. Folke Ström is of the opinion that the pre-Christian Christmas celebration goes back to the so-called alfabloteta fertility feast which seems to have been celebrated in the late autumn til árs ok fridar, in other words for good growth and for peace. The point of time for the annual worship of alfs should be in late autumn, according to a witness from that time. Thus it is told by Sigvat, the court scald of Olav the Holy, that when visiting the village Hov in the year 1018, on the boarder between Norway and Värmland, he was curtly refused lodging for the night no less than three times. The explanation 
for this was finally given by a woman, who anxiously told him that one had alfablot; or as the woman said, "Vi hava heligt (heiligt)". If strangers were permitted entrance over the doorstep, it would have aroused Oden's anger (Ström 1985:89 and 199).

The above examples of pagan cult traditions cannot of course be applied uncritically to the material from Käringsjön. The examples can, however, be used as an impetus for the continuing analysis, since they show that different fertility rituals were practised during different seasons. The question is whether the finds from Käringsjön can be used as a basis for getting a better understanding of when the offerings might have taken place.

\section{SACRIFICIAL DEPOSITIONS}

\section{AND SEASONS}

By making a structural analysis of the find material, in the following pages I will try to get a more varied picture of the character of the sacrifices and the time of year when they can have taken place. The study will be done in two steps. Firstly, the character of the sacrificed object will be discussed and in what way it can be connected with different seasonal activities within agriculture. Secondly, a spatial analysis is done in an attempt to interpret the quantitative distribution of the finds around the lake.

One way of illuminating the point of time for the sacrificial actions in Käringsjön, is to look upon the different types of objects as symbols of different farming activities. Thereby it should be possible to connect these with different seasons of the year. Associated with the spring are thus those tools used in connection with ground-preparing or agricultural activities, such as the spade, the digging stick, the mattock and the draught. Also the tether pale and the lekane, which are connected with grazing and the cattle's well-being, can be seen as spring or summer objects. On the other hand, there are also several tools among the artefacts that are closely linked to activities in late summer and autumn, such as harvest and slaughter. We are dealing partly with different kinds of harvesting implements, such as rakes and a harvest hammer, and partly with bundles of flax along with a cooking-board and a wooden trough for the preparation of foods and drink. Probably many of the clay vessels containing different kinds of food and drink offerings, should also be seen as autumn depositions.

In fig. 5 the find categories mentioned above have been put together into a table, in which they are structured dualistically in relation to a hypothetic "spring versus autumn/ winter" sacrifice. The different compositions of finds in the two columns show convincingly that the cult actions at Käringsjön have taken place both in spring and in autumn. In the spring people visited the isolated lake so that by means of different rituals and sacrifices, they could receive the blessings of the divinity for good growth and the protection of the animals. Later on in the autumn or winter people visited the sacred lake again, then in the form of a thanksgiving to share the year's harvest with the god. No particular spatial distribution concerning these categories' relation to different parts of the sacrificial site could be seen in the find material, however.

It is of course difficult to estimate to what extent the different sacrifices have been practised. However, a simple mathematic example shows that if one vessel was sacrificed every year, in two centuries all in all 200 vessels

\begin{tabular}{|l|l|}
\hline $\begin{array}{l}\text { SPRING SACRIFICE } \\
\text { (ground preparation for sowing } \\
\text { and grazing) }\end{array}$ & $\begin{array}{l}\text { AUTUMN/W'INTER SACRIFICE } \\
\text { (harvest, slaughter and baking) }\end{array}$ \\
\hline K1: spade & K12: harvest harnmer \\
\hline K2: digging stick & F4:1 and F: rake \\
\hline G21: mattock & A5: flax holder \\
\hline A4: draught & AI-2 and F1: bundles of flax \\
\hline F3: tether pale & $\mathrm{Cl}:$ "cooking board" \\
\hline K11: lekane & $\begin{array}{l}\text { El: wooden trough: for proparing } \\
\text { food and drink }\end{array}$ \\
\hline vessel for food and drink offering & vessel for food and drink offering \\
\hline
\end{tabular}

Fig. 5. The table shows the different categories of artefacts that can be connected with agrarian activities during different seasons. The letters show in which trench the find was discovered, while the figures give information on the number of the finds (cf. fig. 4). 
would have been deposited on the site, in other words twice as many vessels as the actual number found in the bog. Such an amount doesn't seem unreasonable in light of the fact that considerable sections of the bog are still unexcavated.

The question of what time of the year the sacrifices may have taken place, can also be illuminated by a closer study of where the artefacts have been deposited on the site. As mentioned earlier, it seems as if the people deliberately chose certain parts of the lake for deposition above others. A deeper analysis of the quantitative distribution of the finds in relation to different cardinal points, confirms this picture. In fig. 6 all areas containing larger

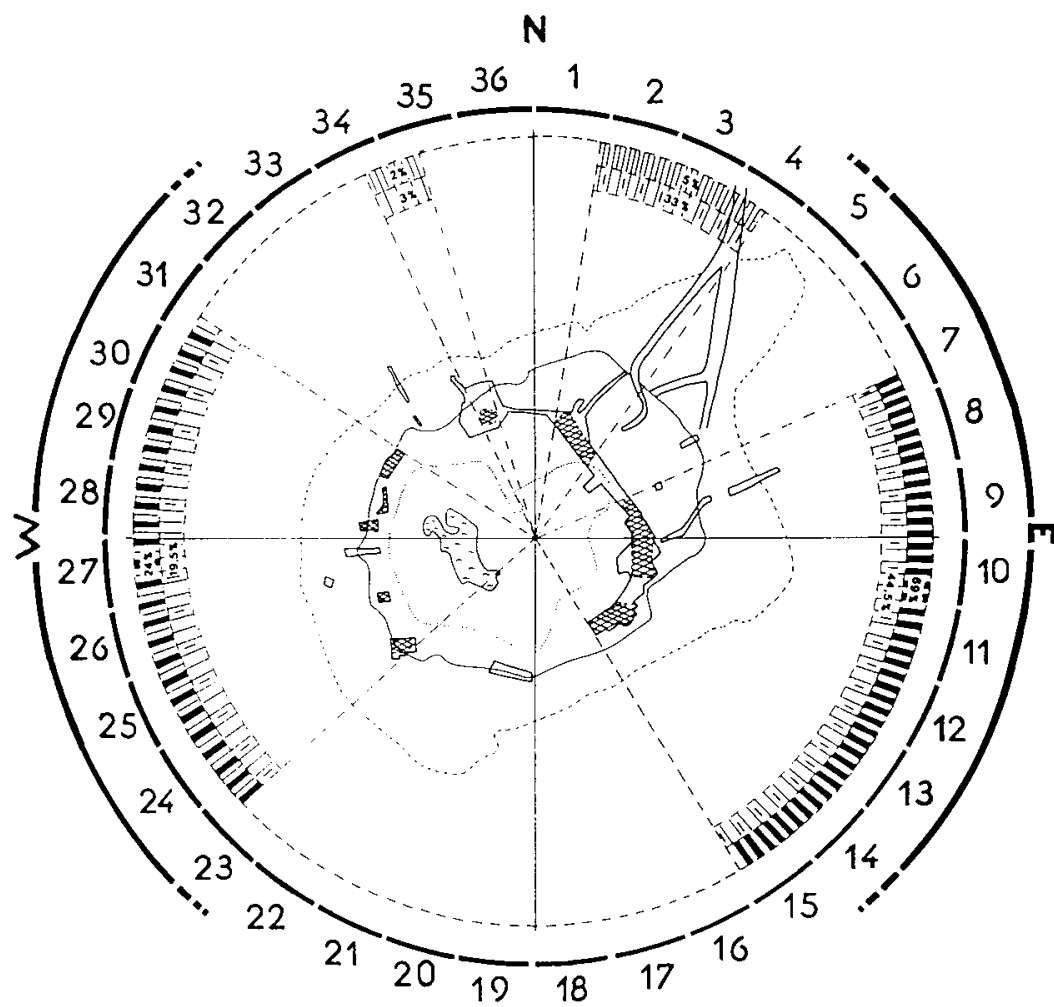

Concentration of finds

$\mathrm{S}$

IC] Number of clay vessels in \% (based on 93 vessels)

[IIII Number of wooden artefacts in \% (based on 36 items)

Fig. 6. The picture shows the spatial distribution of the finds in relation to the sun's movement in the sky. The compass comprises $360^{\circ}$, which have been divided into 36 segments, numbered 1-36 (after Randsborg 1986). The annual movement of the sun is illustrated with a circle. The variations in the sun's ascent in the east are found between segments 5 and 14 , where 5 corresponds to the sun's ascent at midsummer and 14 to it's ascent at midwinter. The setting of the sun in the west is found between segments 23 and 32, where 32 shows the position of the sun's descent at midsummer and 23 it's descent at midwinter. The picture clearly shows that the main part of the sacrificed objects in Käringsjön (vessels 69\% and wooden tools 44.5\%) have been deposited along the eastern and south-eastern shores of the lake, corresponding to segments 7-15. Depositions in larger concentrations have also taken place along the western shore, corresponding to segments $23 / 24$ and 31 , while the depositions in the remaining parts are insignificant. 
find concentrations have been put on a survey plan, in which these are placed in relation to a compass with the four cardinal points marked. By drawing tentative lines between the middle of the compass and the greatest extension of the find concentrations, the sacrificial areas have with greater precision been connected to different cardinal points. From the plan in fig. 6 it is seen that no less than 69 percent of the clay vessels and ca. 44 percent of the wooden artefacts (incl. bundles of flax and rope of lime bast) have been deposited on the eastern shore. The corresponding numbers for the western shore show that 24 percent of the vessels and ca. 19 percent of the wooden artefacts have been deposited here. In addition, sacrifices have also been deposited along the northeastern and north-western shores. The low amount of finds within the latter areas indicates that we are dealing here with considerably less, perhaps even separate, depositions.

The analysis thus shows a very distinct division of the site into an eastern and a western sacrificial area. As mentioned earlier, the spatial distribution of the fine, dated ceramics indicates that both areas have been used for offerings during periods of different length (cf. the discussion above). When the sacrifices were initiated in the beginning of the 3 rd century A.D., the ceremonies primarily took place on the eastern shore. Not until some time during the 4th century was the western shore also being used in the cult.

The deposition of the sacrifices in an eastern and a western area leads to the question of whether there could be any connection with the movement of the sun in the sky during different seasons. In societies practising the fertility cult, it isn't unusual to find a close connection with the ideas of the sun as lifegiving and a guarantor for the rebirth of plants and nature. In particular the sun's position at midwinter is a critical moment, when the sun slowly returns and awakens nature to new life (cf. Kaliff 1997:76).

When comparing the distribution of finds with the rising and setting of the sun, one sees a striking correspondence. Could it be that the variations in the sacrificial depositions along the shores of the lake are connected with the time of year, in the time of day or night, when the offerings took place? The close connection between the concentration of depositions on the south-eastern shore and the sun's ascent on the horizon during midwinter is here of special interest (see fig. 6 segment 14). A comparatively good correspondence also exists between the sun's rising and setting during spring and autumn,while only few depositions can be connected with summer and the time around midsummer.

I would here like to return to the previous discussion concerning why the spatial use of the sacrificial site changed over time. If one presumes that the cult was connected with the rising and setting of the sun, this would mean that the oldest sacrificial depositions on the eastern shore, took place during the sun's rising - in other words as a dawn or morning sacrifice. The fact that the depositions of the 4th century are to a large extent found on the western shore could thereby be seen as a result of changing the time of the sacrifices to coincide with the setting of the sun -in other words as a twilight or evening sacrifice. The changes in the sacrificial depositions, from the eastern to the western shore, could in this way be explained by ideological changes in the cult over time. The change-over from morning to evening sacrifices could here be seen as two analogous contrasts, with on the one hand the sun, the light and life itself as basic parts of meaning, and on the other hand the night, the darkness and death, as its opposite. Perhaps the change in the sacrificial ceremonies should be seen as a result of the ideas of a "new age", concerning which deities - peaceful or warlike - had power over the people and the world.

\section{KÄRINGSJÖN AND THE LOCAL ENVIRONMENT}

What importance did Käringsjön have for the people of that time? Was the lake only used as a local sacrificial site, or did it function as a collective cultic site for the population of a 
larger geographic area - for instance the surrounding district?

In the beginning of the 1940s, at the time of the excavation, the information concerning other ancient monuments in the area was limited. Therefore Käringsjön stood out as a somewhat isolated phenomenon. Since the revised inventory of ancient monuments by the Central Board of National Antiquities (carried out in 1986), the knowledge of ancient monuments has increased considerably. A survey of the register of ancient remains in the area surrounding Käringsjön, shows a rich and varied picture (fig. 7). In several places around the former lake lie isolated graves and groups of graves, primarily consisting of small mounds and stone settings, which could be of the same age as the sacrificial depositions in
Käringsjön. The largest concentration of grave sites lies about one kilometer to the north north-west, and consists of one cemetery, two groups of graves, and three localities with isolated graves. The other accumulation lies approximately 3-400 meters to the south south-east down towards the Nissa Valley. All grave sites here consist of solitary monuments of the stone setting and mound types. In addition to these localities, there are two grave sites consisting of a few mounds and standing stones situated some 400 meters south of Käringsjön. Originally these remains probably were part of a common cemetery, now long since damaged by cultivation. On several sites in the area there are also mounds of a larger size, presumaby dating to the Bronze Age. Finally there are also vast systems of

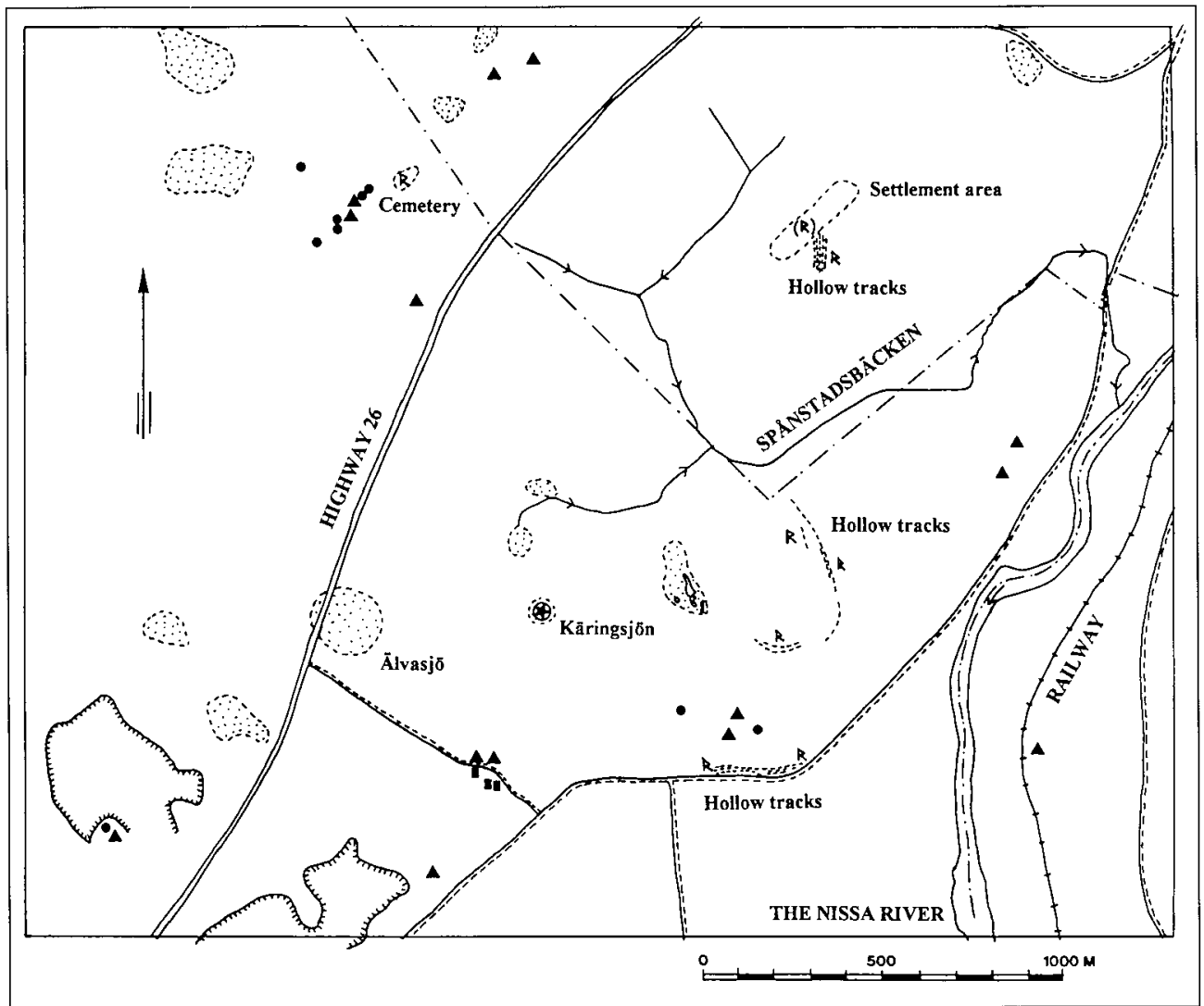

Fig. 7. The known distribution of ancient monuments in the area close to Käringsjön. Based on CBNA's Register of Ancient Monuments and the Economic Map. Symbols: Black triangle - mound; Black circle - stone-setting; Black rectangular-standing stone; Dotted area-wetland. Drawing: Anne Carlie. 
hollow tracks, bearing witness to the importance of the valley as a communication route.

I should mention that the grave sites accounted for in fig. 7 are not the only sites along the Nissa Valley. On the contrary, they constitute only a small part of a considerable band of graves lying on both sides of the valley. Thus from a settlement point of view, Käringsjön is situated in a rich district. In spite of this, no settlements were previously known from the area-neither from the Bronze nor the Iron Age. However, in the spring of 1997 a settlement area some 2-300 meters long was found in connection with a private survey, about one kilometer north-east of the former sacrificial lake (together with Lennart Carlie, the County Museum of Halland). The settlement, identified through rich finds of firecracked stones and pottery sherds, is situated on a plateau-like ridge in a north-east - southwest direction. According to L. Carlie, who has great experience from Iron Age settlements in southern Halland, the character of the surface finds indicates that we are probably dealing with a site from the Roman Iron Age. In the area close to the sacrificial site, additional sites have topographical conditions, conducive to potential settlements. In the last few years archaeological investigations in the southern part of Halland have revealed settlements from the Roman period, especially those consisting of isolated farms. However, regular villages have also existed. In the later part of the $1980 \mathrm{~s}$ the remains of a Roman Iron Age village, consisting of no less than six contemporaneous farms gathered around an open area, were investigated at Brogård, outside Halmstad (Carlie 1992).

It is still too early to draw any conclusions from the picture of ancient monuments as to the importance of Käringsjön, and whether the site should be understood from a local or regional point of view. However, I expect that future analysis of settlement groupings and structures within the region can be used as a basis for a continued discussion. In the meantime the question concerning the status of Käringsjön can only be illuminated through the find conditions on the site. It is primarily the number of finds, but also their particular spatial distribution around the lake, that speak in favour of a local site, used by the population of a few farms or villages in the Nissa Valley and its nearby area. If Käringsjön had functioned as a regional sacrificial site for a larger district, this circumstance would also have been shown in the deposition and intensity of the find material.

In a continued discussion of Käringsjön, one must also deal with the theophoric placenames. A preliminary survey of the placename material here shows that if Käringsjön is to be seen as the lake of the female divinity, there lies some five kilometers to the northeast, on the eastern side of the river Nissan, a small overgrown lake with the name of Torsjön. The lake is mentioned for the first time in 1452 and is then called Thoresiø (oral comm. Ulla Sjögarne, the Archive of Placenames, Uppsala). No attempts have been made to explain the etymology of the name. As theophoric place-names usually are found in pairs, with one female and one male deity as prefixes (Brink 1984:169), it is not impossible that the prefix actually refers to the god Tor, in other words the lake of the god Tor.

\section{THE ABANDONING OF THE SITE}

As previously mentioned the finds from Käringsjön show that the small lake, after the 4th century, was no longer used for sacrifices. Different hypotheses have been put forth, in order to explain why the site was abandoned. Already in Arbman's publication, the geologist Sandegren discussed the possibility of a connection between the higher water-level around 400 A.D. and the discontinuing of the sacrificial depositions. The rising water-level must gradually have made the wooden ramps along the shores increasingly waterlogged and thereby made it difficult to continue sacrificing in the lake (Sandegren 1945:157).

In recent years, as archaeologists have become more and more interested in the practising of ancient Nordic religion from a broader perspective, new models for interpre- 
tation have been put forth. One of the scholars who has specifically discussed Iron Age religion and traditions of sacrifice is Charlotte Fabech. On the basis of her studies of Iron Age sacrificial finds in southern Scandinavia, Fabech sees several important changes within the sacrificial traditions around 400 A.D. One such change is marked by the fact that offerings in wetlands cease in favour of places on solid ground. At the same time new types of offerings appear, in the form of funeral sacrifices and gold bracteates that can be connected with settlements of some importance. The diminished importance of wetlands as sacred sites is also marked, from the 6th century, by the appearance of goldfoil figures (guldgubbar). According to Fabech, the changes in the character of sacrifices indicate that the collective fertility sacrifices were replaced during the Migration period by private sacrifices linked to a newly established aristocracy (Fabech 1991:290ff).

The type of model argued for by Charlotte Fabech is foremost useful for understanding changes in society on a wider regional level. When trying to transmit the reasoning to phenomena and courses of change on a local level, the model doesn't seem quite as convincing. For the discussion on Käringsjön Fabech's hypothesis would imply that the discontinuity of the sacrificial traditions were a consequence of changes in the religious cult (cf. Artelius 1993:52). Here one can ask why the local population in the area, after having made sacrifices to the sacred powers of the lake for many generations, suddenly abandoned their traditions. Besides, would the people voluntarily accept a change of cult? The model above thus presupposes that the change in religious cult was a coercive act by an external power or force - for example a local chief or petty king. In the present situation there are no indications, neither in the archaeological nor written material, that speak for a political and religious centre in the beginning of the Migration period in the area around present-day Halmstad, where the river Nissan has its outlet. Grave and settlement finds instead give the impression of a peaceful agrarian society, without any higher aristocracy or features of war. This picture of the region may of course change with future excavations and research contributions. Thus it should be mentioned that Lennart Carlie, within the so-called Uppakra Project, is working on a thesis concerning the Iron Age settlement structure and regional identity in southern Halland. In this work issues concerning the social stratification of the settlements will also be discussed. The only settlement of central importance known today within the region, is found aproximately 2.5 kilometers north of Halmstad, in Slöinge along the valley of the Suse River. Archaeological investigations at the site, carried out in the beginning of the $1990 \mathrm{~s}$, revealed a farm of central importance that existed probably from the 4th century and into the Viking Age. Numerous finds of goldfoil figures, pieces of glass beakers, glass bead manufacture and metalwork on the site, show that the religious cult as well as trade and crafts has been linked to the magnate's farm (Lundqvist 1996).

It is of course possible that changes in the conceptions and ideals of society indirectly affected people's religious world-view, causing them to voluntarily abandon the old sacrificial site. Another possible scenario could be that the responsibility for sacred actions was taken over by a new family or farm in the area, and for this reason cultic activities were moved to another corresponding site nearby. It is interesting that such a potential sacrificial site actually lies only a few hundred meters west of Käringsjön, in the village of Älvasjö. Nowadays Älvasjö lies at highway number 26, where the modern-day direction of "Nissastigen" divides the village into two parts. What isn't quite clear from the maps of today is that the village farms, in the same way as 300 years ago, are situated around the former and now drained Älvasjö. The name Älvasjö is mentioned for the first time in 1595, at that time written as "Elfveplet". Seven years later, in 1602, the spelling "Eluisöe" is found. The etymological meaning of the name is not clear. Jöran Sahlgren argues in Ortnamnen i Hallands län (1948) that the prefix probably goes 
back to the ancient Hallandic genitive form of the male name Älfvar, while the suffix presumably comes from -ryd, in other words a clearance in the forest. Sahlgren's some-what strange comment concerning the suffix is explained by the fact that he had no knowledge of the existence of the former lake (Sahlgren 1948:174).

No further attempts to explain the name have been put forward (oral comm. Ulla Sjögarne, the Archive of Place-names, Uppsala). Could it be that simple, however, that the prefix actually refers to the word "älva", and that the name therefore implies to the Lake of the Elves? According to Folke Ström, the Elves of the later folklore are probably a subsidiary branch of the Alfs of the ancient Nordic mythology. In his poetic Edda, Snorre mentions Alfs as equal to Æsir and Vanir, which can indicate that they previously had a more prominent position in the older religious world-view. According to Snorre, there were two kinds of Alfs: light alfs living in the divine dwelling of Alfheim, and black alfs living in the underworld. While interpretations concerning the mysterious origin of the black alfs have connected them with the spirits of the dead, light alfs on account of the so-called alfablotet have been interpreted as spirits connected with a fertility cult (Ström 1985:199).

If the name Älvasjö corresponds to the Lake of the Elves or Alfs, this could be the site that replaced Käringsjön as a sacrificial site. The assumption is of course hypothetical, but it could easily be confirmed or rejected by archaeological investigations of the shores of the former lake.

\section{CONCLUDING REMARKS}

In this paper Käringsjön, an old and wellknown archaeological site, was taken up to renewed discussion. The site was used for sacrifices during the Late Roman Iron Age and is situated in Halland, south-west Sweden. In connection with archaeological investigations in the beginning of the 1940s, wooden ramps were found along the shores of the ancient lake, together with large amounts of pottery and different kinds of wooden artefacts. Based on the character and composition of the finds, the site has been interpreted as a peaceful sacrificial site used by the agrarian population in connection with the practising of the fertility cult.

The aim of this essay was to increase our understanding of the sacrificial site and the different cultic activities that once took place. The renewed analysis of the site and the finds revealed a spatial division of the sacrificial site into an eastern and a western sacred area. When the site was taken into use in the beginning of the 3rd century A.D., the depositions primarily took place along the south-eastern and eastern shores. During the 4 th century the depositions to a great extent moved to the western shore. The spatial distribution of the sacrifices here shows a close connection with the sun's movement in the sky at rising and setting during the spring and autumn. The connection between the concentration of finds along the south-eastern shore and the position of the sun's ascent on the horizon at midwinter, is particularly conspicuous. Against this background the spatial changes in the sacrifices, with a shift from the eastern to the western shore, can most likely be understood as ideological changes in the cult over time. A structural analysis of the composition of the sacrificial finds strengthens the picture of the sacred actions primarily taking place in spring and in autumn/winter.

The paper also discussed the question of Käringsjön's importance, and whether the site could have functioned as a local or regional cultic site for the surrounding region. On the basis of the special deposition of the find material around the lake, the hypothesis was made that the lake probably should be seen as a local sacrificial site used by the population of a few farms or villages in the nearby area. However, a future complementary analysis of the settlement structures in the surrounding region is needed, with attempts at identifying phenomena or sites of a religious/ideological character.

Finally, possible reasons for the abandon- 
ment of the sacrificial site were touched upon. Two conceiveable scenarios were put forth, both of which are based on the assumption that the lake was voluntarily abandoned. In the first scenario the reason for abandoning the site is attributed to changes in peoples religious world-view. In the second case the desertion is seen as a result of the responsibility for the sacred actions being taken over by a new family or farm. In order to emphasize this change, one chose to move the cultic activities to another site in the area. The now drained Älvasjö, lying only a few hundred meters from Käringsjön, is suggested as a possible new sacrificial site, in view of the etymology of the name.

\section{English revised by Laura Wrang.}

\section{REFERENCES}

Arbman, H. 1945. Käringsjön. Studier i halländsk järnålder. KVHAA:s handlingar del 59:1. Stockholm.

- 1954. Hallands forntid. In: Hallands historia. Från äldsta tid till freden i Brömsebro 1645. Halmstad.

Arne, T.J. 1919. Stendösar från järnåldern. Fornvännen. Stockholm.

Artelius, T. 1993. Offerfynden i Käringsjön. Perspektiv från en halländsk mossgöl. Fynd $n r 2$.

Becker, C.J. 1970. Zur frage der eisenzeitlichen Moorgefässe in Dänemark. In: Jankuhn, H. (Ed). Vorgeschichtliche Heiligtümer und Opferplätze in Mittel- und Nordeuropa. Göttingen.

- 1971. Mosepotter fra Danmarks jernalder. Problemer omkring mosefundne lerkar og deres tolkning. Aarbøger for nordisk oldkyndighed og historie. København.

Bloch, M. 1985. From cognition to ideology. In: Fardon, R. (Ed). Power and knowledge: anthropological and sociological approaches. Scottish Academic Press. Edinburgh.

Brink, S. 1984. Ortnamn som källa i historisk forskning. Fornvännen 79. Stockholm.

Burström, M. 1991. Arkeologisk samhällsavgränsning. En studie av vikingatida samhällsterritorier i Smålands inland. Stockholm Studies in Archaeology 9. Stockholm.

Carlie, L. 1992. Brogård - ett brons- och järnålderskomplex $i$ södra Halland. Dess kronologi och struktur. Hallands länsmuseers skriftserie No 6. Lund.

Colpe, C. 1970. Theoretische Möglichkeiten zur Identifizierung von Heiligtümer und Interpretation von Opfern in ur- und parahistorischen Epochen. In: Jankuhn, H. (Ed). Vorgeschichtliche Heiligtümer und Opferplätze in Mittelund Nordeuropa. Göttingen.

Erixon, S. 1917. Offerkasten på Svedvi allmänning samt något om offerkastar $\mathrm{i}$ allmänhet. Västmanlands fornminnesförenings tidskrift.

- 1929. Offerkastar utan dödsmotiv. Fataburen.

Fabech, C. 1991. Samfundsorganisation, religiøse ceremonier og regional variation. In: Fabech, C. \& Ringtved, J. (Eds). Samfundsorganisation og Regional variation. Norden i romersk jernalder ogfolkevandringstid. Jysk Arkæologisk Selskabs Skrifter XXVII.

Hagberg, U-E. 1967. The archaeology of Skedemosse. Bd II. The Votive Deposits in the Skedemosse Fen and their Relation to the Iron-Age Settlement on Öland, Sweden. The Royal Swedish Academy of Letters, History and Antiquities.

Hatt, G. 1937. Landbrug i Danmarks Oldtid. København.

Hjørungdal, T. 1991. Det skjulte kjønn. Patriarkal tradisjon og feministisk visjon $i$ arkeologien belystmedfokus på en jernalderskontekst. Acta Archaeologica Lundensia series in $8^{\circ}$. Nr 19. Lund.

Holtsmark, A. 1992. Fornnordisk mytologi. Tro och myter under vikingatiden. Studentlitteratur. Lund.

Hultgård, A. 1996. Fornskandinavisk kult - finns det skriftliga källor? In: Engdahl, K. \& Kaliff, A. (Eds). Religion från stenålder till medeltid. RA Ä. Arkeologiska undersökningar. Skrifter nr 19. Linköping.

Kaliff, A. 1997. Grav och kultplats. Eskatologiska föreställningar under yngre bronsålder och äldrejärnålderiÖstergötland. Aun 24. Uppsala.

Levi-Strauss, C. 1984. Det vilda tänkandet. Arkiv moderna klassiker.

Lindberg, A. 1994. Järnålderns stamsamhälle $i$ Halland. En studie med utgångspunkt frän Käringsjön. Seminar paper. Stockholm.

Lundborg, L. 1972. Undersökningar av bronsåldershögar och bronsåldergravar $i$ södra 
Halland. Höks, Tönnersjö och Halmstads härader under åren 1854-1970. Hallands museum 2. Halmstad.

Lundqvist, L. 1996. Slöinge - en stormansgård från järnåldern. In: Slöinge och Borg. Stormansgårdar i öst och väst. Riksantikvarieämbetet. Arkeologiska undersökningar. Skrifter nr 18. Linköping.

Randsborg, K. 1986. The Coffin and the Sun. Demography and Ideology in Scandinavian Prehistory. Acta Archaeologica vol. 551984. København.

Renck, A. M. 1996. Ritualen - hjärtat i religiös/ ideologisk och politisk förändring. In: Renck, A.M. \& Stensköld, E. (Eds). Aktuell Arkeologi V. SAR nr 30. Stockholm.

Sahlgren, J. 1948. Ortnamnen i Hallands län. Del 1. Bebyggelsenamnen i södra Halland.

Sandegren, R. 1945. Torvgeologisk och pollenanalystisk undersökning. In: Arbman. H. Käringsjön. Studier $i$ halländsk järnålder. KVHAA:s handlingar del 59:1. Stockholm.

Steinsland, G. \& Vogt, K. 1981. "Aukinn ertu Uolse ok vpp vm tekinn". En religionshistorisk analyse av Volsatăttri i Flateyjarbok. Arkiv för Nordisk Filologi 96. Lund.

Stenberger, M. 1979 (3:e uppl.). Det forntida
Sverige. Lund.

Stjernquist, B. 1973. Das opfermoor in Hassle Bösarp, Schweden. Acta Archaeologica. Vol XLIV. København.

Ström, F. 1985. (3:e uppl). Nordisk hedendom. Tro och sed i förkristen tid. Akademiförlaget.

Tacitus, (1976). Germania. The Agricola and the Germanis. Translation with an introduction by H. Mattingly. London.

Turville-Petre, E.O.G. 1964. Myth and Religion of the North. The Religion of Ancient Scandinavia. Worcester and London.

\section{REGISTER AND MAPS}

The Central Board of National Antiquities' Register of Ancient Monuments for Övraby and Enslöv parishes.

The Economic Map, sheet 4C 8e.

\section{ORAL SOURCES}

Antiquarian Lennart Carlie, the Institution of Halland County Museums, Halmstad

Docent Ronnie Liljegren, the Institution of Quarternary Geology, Lund University

Antiquarian Ulla Sjögarne, the Archive of Placenames, Uppsala 
